\title{
Beyond hydrogeologic evidence: challenging the current assumptions about salinity processes in the Corangamite region, Australia
}

\author{
P. G. Dahlhaus • J. W. Cox • C. T. Simmons • \\ C. M. Smitt
}

\begin{abstract}
In keeping with the standard scientific methods, investigations of salinity processes focus on the collection and interpretation of contemporary scientific data. However, using multiple lines of evidence from nonhydrogeologic sources such as geomorphic, archaeological and historical records can substantially add value to the scientific investigations. By using such evidence, the validity of the assumptions about salinity processes in Australian landscapes is challenged, especially the assumption that the clearing of native vegetation has resulted in rising saline groundwater in all landscapes. In the Corangamite region of south-west Victoria, salinity has been an episodic feature of the landscapes throughout the Quaternary and was present at the time of the Aboriginal inhabitants and the first pastoral settlement by Europeans. Although surface-water salinity has increased in some waterways and the area of salinised land has expanded in some landscapes, there is no recorded
\end{abstract}

Received: 11 July 2007 / Accepted: 16 April 2008

\section{P. G. Dahlhaus (『)}

School of Science and Engineering,

University of Ballarat, P.O. Box 663, Ballarat 3353, Australia e-mail: dahlhaus@netconnect.com.au

Tel.: +61-3-53413994

J. W. Cox

CSIRO Land and Water, Private Bag 2, Glen Osmond 5064,

Australia

e-mail:Jim.Cox@csiro.au

\section{T. Simmons}

School of Chemistry, Physics and Earth Sciences,

Flinders University of South Australia, GPO Box 2100, Adelaide 5001, Australia

e-mail: craig.simmons@flinders.edu.au

C. M. Smitt

Hyder Consulting Pty Ltd,

16/31 Queen Street, Melbourne 3000, Australia

e-mail: Chris.Smitt@hyderconsulting.com evidence found which supports significant rises in groundwater following widespread land-use change. In many areas, salinity is an inherent component of the region's landscapes, and sustains world-class environmental assets that require appropriate salinity levels for their ecological health. Managing salinity requires understanding the specific salinity processes in each landscape.

Résumé En se conformant aux méthodes scientifiques standard, les études de l'acquisition de la salinité se concentrent sur la collecte et l'interprétation de données scientifiques contemporaines. Toutefois, l'utilisation de filières multiples de données provenant de sources non hydrogéologiques telles que des compilations géomorphologiques, archéologiques et historiques peut ajouter de façon substantielle de la valeur aux études scientifiques. En utilisant de telles données, la validité des hypothèses concernant l'acquisition de la salinité dans les espaces naturels Australiens est mise en question, en particulier l'hypothèse que le défrichement de la végétation indigène a entraîné une remontée d'eau souterraine saline dans toutes les espaces naturels. Dans la région de Corangamite du Sud Ouest du Victoria la salinité a été une caractéristique épisodique des espaces naturels pendant tout le Quaternaire et était présente $\mathrm{du}$ temps des habitants Aborigènes et des premiers peuplements pastoraux par les Européens. Bien que la salinité de l'eau de surface ait augmentée dans quelques cours d'eau et que la superficie de terres devenues salines se soit développée dans certaines régions, aucune preuve documentée n'a été trouvée qui confirme des remontées d'eau souterraine significatives à la suite de modifications extensives de l'utilisation du sol. Dans de nombreuses régions la salinité est une composante inhérente aux espaces naturels de la région, et entretiennent une richesse environnementale de niveau mondial qui exige des niveaux de salinité convenant à leur santé écologique. La gestion de la salinité exige la compréhension du développement spécifique de la salinité dans chaque espace naturel.

Resumen De acuerdo con los métodos científicos, las investigaciones de procesos de salinización se centran en 
la recolección e interpretación de datos científicos modernos. Sin embargo, el uso de líneas múltiples de evidencia de fuentes no hidrogeológicas -tales como registros geomórficos, arqueológicos e históricos-pueden agregar un valor sustancial a las investigaciones científicas. Mediante el uso de tales evidencias, se cuestiona la validez de las hipótesis sobre procesos de salinización en ambientes australianos, especialmente la noción que la eliminación de la vegetación nativa ha resultado en en la elevación de agua subterránea salina en los ambientes. En la región de Corangamite, al sudoeste de Victoria, la salinidad ha sido una característica episódica del paisaje durante el Cuarternario y estaba presente en tiempo de los habitantes aborígenes y de los primeros asentamientos pastoriles europeos. Aunque la salinidad de cuerpos de agua superficiales se ha incrementado y las tierras alinizadas se han expandidos en algunos ambientes, no se encontraron registros que sustenten que la elevación del agua subterránea fue la consecuencia de la generalización de cambios en el uso de la tierra. En muchas áreas, la salinidad es un componente inherente a la región, que posee "activos"ambientales que requieren de niveles apropiados de salinidad para su sanidad ecológica. La gestión de la salinidad supone una comprensión de los procesos de salidad en cada ambiente.

Keywords Salinisation - Saline wetlands - Conceptual models $\cdot$ Corangamite $\cdot$ Australia

\section{Introduction}

The common conception for the salinisation of land and water resources in Australian dryland agricultural regions is that of evaporative concentration of salts from shallow water tables that have risen following the clearing of native vegetation for agriculture (Peck and Williamson 1987; George et al. 1997; Salama et al. 1999). This paper argues a major shift away from that notion, by linking evidence from the fields of geomorphology, archaeology and environmental history. Using data sources beyond the usual hydrogeologic evidence (such as groundwater hydraulics, hydrochemistry, isotopes, modelling etc.) has developed more empirically accurate conceptualisations for salinity processes that are occurring in the Corangamite region of south-eastern Australia. Examining the salinity processes over an extended timeline can provide a context for the current day observations and lead to a different conclusion than that based on short-term monitoring and prediction. It is contended that supplementing hydrogeological research with multiple lines of evidence from non-scientific sources can substantially add value to such scientific investigations.

Dryland salinity impacts on the water quality, agricultural land, environmental assets, urban and rural infrastructure, and cultural heritage assets of the Corangamite region in south-west Victoria. The most urgent threats are to the urban water supplies of the region's two major provincial cities - Ballarat and Geelong - and to wetlands of international significance listed under the Ramsar Convention and habitats for migratory birds subject to international treaties. In the 1.3 million ha of the Corangamite region, over 17,000 ha of salt-affected land have been mapped and the area continues to expand (Nicholson et al. 2006).

The Corangamite regional population is approximately 400,000 persons and is growing at $5.2 \%$ per year, with manufacturing, tourism, agriculture and forestry as major industries. The climate is generally warm temperate, with winter/spring dominant rainfall that varies from 400 to $2,000 \mathrm{~mm}$ annually across the region. Four drainage basins - the Barwon, Moorabool, Lake Corangamite and Otway Coast - cover the region, and the major drainage systems are those of the Barwon, Woady Yaloak, Moorabool, Leigh, Gellibrand and Curdies rivers. Over 1,500 lakes and wetlands are a feature of the region, including the internationally significant Lake Corangamite, Lake Colac, Lake Murdeduke and Lake Connewarre (Fig. 1).

In 2001, the National Land and Water Resources Audit released the "Australian Dryland Salinity Assessment 2000" (NLWRA 2001). The predictions for the Corangamite region were dire; with the worst-case scenario suggesting that $48.5 \%$ of agricultural land is at risk from shallow water tables by 2050 , costing the region AUD\$ 29 million per year and with over $40 \%$ of the region's wetlands threatened by 2050 . Based on the predictions of increasing salinity, the Corangamite region is nominated as one of the priority regions in Australia, under the National Action Plan for Salinity and Water Quality (CoAG 2000).

The main cause of the salinity is assumed to be rising saline groundwater following widespread clearing of native vegetation in the mid to late nineteenth century for pastoral settlement, agriculture and mining (NLWRA 2001). Since the first regional salinity strategy in 1992, approximately AUD $\$ 50$ million of government funding has been provided to the region for salinity management, and many millions of dollars in landholder, industry and community contributions. This funding has been provided to establish over 5,000 ha of trees, treat around 1,500 ha of salt-affected land, establish over 500 groundwater monitoring bores and support several major research programs (Nicholson et al. 2006).

This paper reviews the evidence for salinity in the Corangamite region during the Quaternary Period and time since first European settlement. The validity of the current assumption that the clearing of native vegetation has resulted in rising saline groundwater in all landscapes throughout the region is challenged. Although the cause (land clearing) and effect (salinisation) has been well established in other areas of Australia (Ghassemi et al. 1995), it is not universally applicable in this region. The implications for the current salinity management actions are discussed.

\section{Geological, geomorphic and hydrogeologic framework}

Three broad-scale geomorphic components make up the Corangamite region: the Victorian Western Uplands in the 


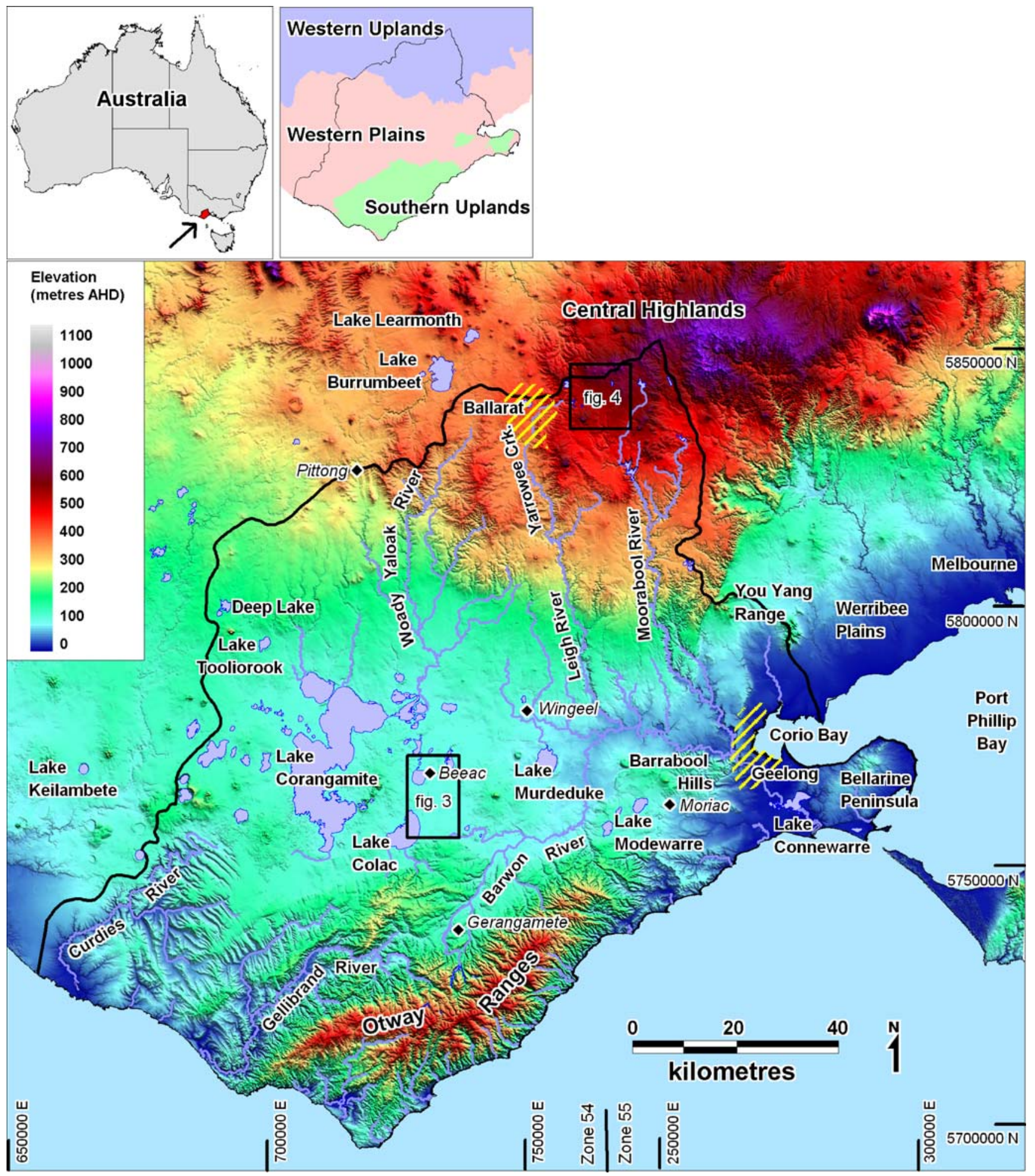

Fig. 1 Location of the Corangamite region delineated by the solid black line. The diamonds are the locations of the discharge monitoring reference sites. The yellow lines indicate the extent of the City of Ballarat and the City of Geelong (i.e. the urban area)

north; the Victorian Western Plains in the centre; and the Victorian Southern Uplands in the south (Joyce et al. 2003). The basement rocks of the Corangamite region are prominent in the undulating hills and broad valleys which characterise the landscapes of the Western Uplands. These Cambrian and Ordovician age sedimentary rocks formed as deep-marine turbidite sediments, resulting in sequences of quartz-rich arenites and black shales. Tectonic activity from the Late Ordovician to Early Silurian periods folded and faulted the rocks, metamorphosing the shales into phyllite and quartz-mica schists, and injecting quartz veins (some of which were auriferous). A number of granite 
bodies were intruded during the Late Devonian and the associated contact metamorphism formed aureoles of hornfels. The granites have been subsequently exposed by the extensive erosion during the Palaeozoic and Mesozoic eras that removed several kilometres of overlying sedimentary rocks.

Uplift and erosion during the Palaeogene resulted in the widespread deposition of gravels and sands over much of the Western Uplands. These are now sporadically distributed as ferruginised and silicified gravel caps at various elevations. Deep weathering during the Neogene formed a thick regolith of bleached shales, sandstones and kaolinised granite. A marine transgression and regression during the Pliocene deposited sands which now fringe the Palaeozoic rocks as a dissected tableland. During the Pliocene and Pleistocene, volcanic eruptions filled the broad valleys to form elongate basalt plains and a variety of other volcanic landforms. The placer deposits of gold in the buried stream sediments, termed deep leads, were later mined.

The Western Plains, the largest of the three geomorphic units, comprise gently undulating plains formed on both volcanic and sedimentary rocks. Volcanic plains of Pliocene and Pleistocene age basalt make up the majority of the geomorphic unit. These basalts are less than $50 \mathrm{~m}$ thick and are younger than 4.6 million years, with the largest volume emplaced around 2 million years ago (Price et al. 2003). The youngest eruption points are represented by cinder cones, maars, lava shields and stony basalt barriers, some of which are less than 100,000 years old. The basalts unconformably overlie extensive sand plains of Pliocene age. These sands, which are generally less than $20 \mathrm{~m}$ thick, are exposed in places where they were not covered by the volcanic lavas. Beyond the volcanic plains to the south west, the sand plains have been dissected, exposing the underlying limestone and marl of Miocene age.

The southern portion of the Corangamite region is dominated by the Southern Uplands, comprising the deeply dissected Otway Ranges, moderately dissected Barrabool Hills and low hills of the Bellarine Peninsula. All three landscapes have been formed by the uplift of structurally controlled blocks of lithic sedimentary rocks of the Lower Cretaceous age (i.e. the Otway Group rocks). The Barrabool Hills and Bellarine Peninsula are smaller fault-bounded uplift blocks at lower elevations than the Otway Ranges, and are generally more planar and less deeply dissected. The northern flanks of the Otway Ranges are fringed by gravels, sands and fine-grained sedimentary rocks of Palaeogene age.

\section{Groundwater flow systems}

Seventeen groundwater flow systems (GFS) were delineated in the Corangamite region (Fig. 2) consistent with the National Land and Water Audit framework for dryland

\section{Dominantly local flow systems}

\begin{tabular}{|l|}
\hline Quaternary sediments \\
Scoria cones and stony rises \\
Highlands gravel caps \\
Heytesbury marl \\
Gerangamete marls \\
Otway Group - Barrabool Hills \\
Granitic rocks \\
Older volcanics \\
Otway Group - Otway Ranges \\
\hline
\end{tabular}

\section{Dominantly intermediate flow systems}

\begin{tabular}{|l|}
\hline Pliocene sands \\
\hline Wiridjil Gravels \\
\hline Palaeozoic sedimentary rocks \\
Central Highlands volcanics \\
\hline
\end{tabular}

\section{Dominantly regional flow systems}
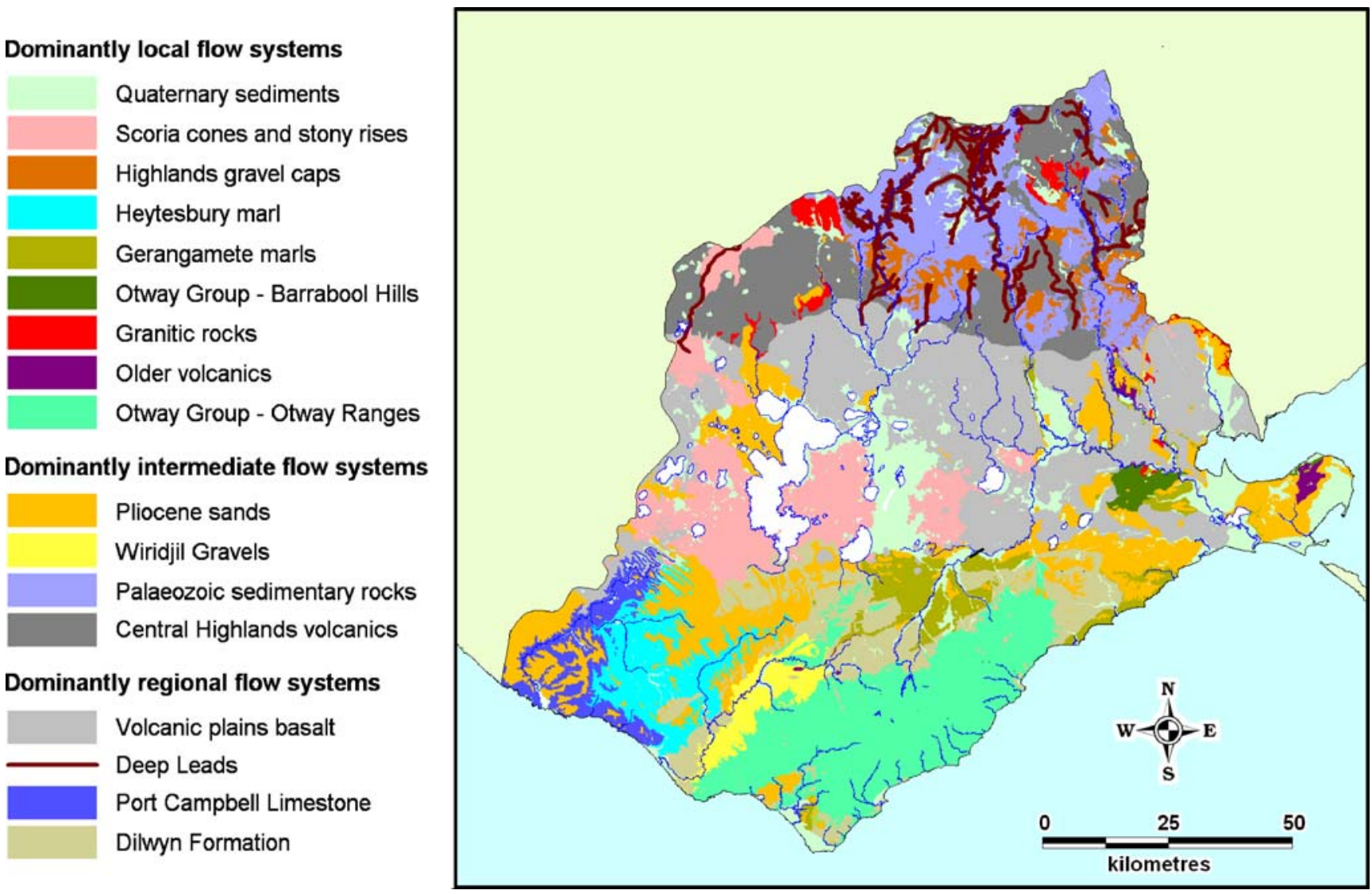

Fig. 2 Groundwater flow systems of the Corangamite region 
salinity management in Australia (NLWRA 2001). The GFS characterise similar landscape-groundwater systems which give effect to similar salinity issues, and where similar management options may apply. The boundaries of the systems are based on the region's geological units which have been grouped according to their hydrogeological characteristics, as determined by consensus of opinion reached at a 3-day GFS workshop with 55 regional experts who have conducted numerous investigations over the past decades (Dahlhaus et al. 2002). The flow systems do not represent a traditional hydrogeological map, but rather they are a tool for assessing hydrological responsiveness of a catchment. They are characterised by their hydrological responses and flow paths into dominantly local, intermediate and regional systems, viz:

- Local systems. Groundwater flows over distances of less than $5 \mathrm{~km}$ within the confines of surface water subcatchments. Water tables rise rapidly and saline discharge typically occurs within 30-50 years of widespread landuse changes such as clearing native vegetation for agricultural development. These systems can respond rapidly to salinity management practices, and afford opportunities to mitigate salinity at a local scale.

- Intermediate systems. Groundwater flows over distances of 5-30 km and may occur across sub-catchment boundaries. They have a greater storage capacity and generally higher permeability than local systems and take longer to 'fill' following increased recharge. Increased discharge typically occurs within 50 100 years of widespread clearing of native vegetation. The extent and responsiveness of these systems present greater challenges for salinity management.

- Regional systems. Groundwater flow occurs over distances exceeding $50 \mathrm{~km}$ at the scale of river basins. They have a high storage capacity and permeability and they take much longer to develop increased groundwater discharge than local or intermediate flow systems-probably more than 100 years after widespread clearing of native vegetation. The scale of regional systems makes locally based catchmentmanagement options ineffective and these systems will require widespread community action and major landuse change to secure improvements in water balance.

In accord with the national and state policies, the salinity management actions in the Corangamite region are based on the response of the GFS implicated in the salinity process (Dahlhaus 2004). This is mainly achieved through the establishment of vegetation in areas targeted for recharge or discharge management (Nicholson et al. 2006).

\section{Salinity during the Quaternary period}

Evidence of salinity in the Corangamite landscapes throughout the Quaternary Period is provided by both the geomorphic features and the archaeological evidence of human occupation.

\section{Salinity in the Pleistocene (1.1 Ma-11 ka)}

The Western Plains, which cover approximately $40 \%$ of the Corangamite region, are noted for their shallow lakes and wetlands, many of which are saline. The majority of the lakes are bordered by lunettes, crescentic dune-like landforms that record the hydrologic conditions of the adjacent lake (Bowler 1983). Clay lunettes are associated with saline conditions, as the salt efflorescence causes the near surface clays to form a soft fluffy pelletal layer which is then deflated by wind. Sand lunettes are formed as beach deposits by both wave and aeolian accumulation during lake-full conditions, and are associated with lowsalinity water.

Dating and stratigraphic studies of the lunettes in the Colac-Beeac area has been undertaken by Dimmer (1992) and Tickell and King (1992) and complied by Edwards et al. (1996). Their research confirms a broad-scale transition from low salinity conditions associated with high lake levels, increased surface runoff and high water tables around 30,000-20,000 years BP followed by high-salinity conditions associated with lower lake levels and lower water tables during the last glacial 20,000-10,000 years BP. This observation correlates well with the record of climatic oscillations in southern Australia (Wasson and Donnelly 1991; Williams et al. 1993).

Further evidence for the varied lake levels is provided by a recently acquired high-resolution digital elevation model in the region (Fig. 3). The successive episodes of lunette building is shown by the truncation of larger lunettes (Fig. 3, arrow A) as lake levels have risen and nesting of smaller lunettes within larger ones as the lake levels have dropped (Fig. 3, arrow B). The geomorphology fits with the general observations on changing lake typology during the changes from maximum lake level (megalake stage) to a drier phase in which the lake sediment composition is increasingly influenced by groundwater (Williams et al. 1993).

It is likely that humans have inhabited the Corangamite region for at least 35,000 years (Mulvaney and Kamminga 1999) although little is known of the early inhabitants. An important study of Aboriginal land-use and demographics of the Lake Corangamite Drainage Basin has been published by McNiven (1998), who contends that only four lakes in the drainage basin have seasonal salt-levels within the range tolerable for human consumption $(<4,000 \mathrm{ppm})$ - viz: lakes Logan, Tooliorook, Deep and Colac. Based on the correlation of the locations and number of artefact sites and salinity of the lakes around which they are found, he convincingly argues that the availability of freshwater is the singularly most important limiting factor for past Aboriginal land-use of the drainage basin. McNiven (1998) proposes a model in which the development of a closed drainage basin has slowly increased the salinity of the lakes since the Late Pleistocene, and the Aboriginal settlement patterns were restructured in response to individual water sources becoming too saline to drink. Commencing with a sporadic occupation concentrated around the fresher water sources during the Late Pleistocene, Aboriginal 


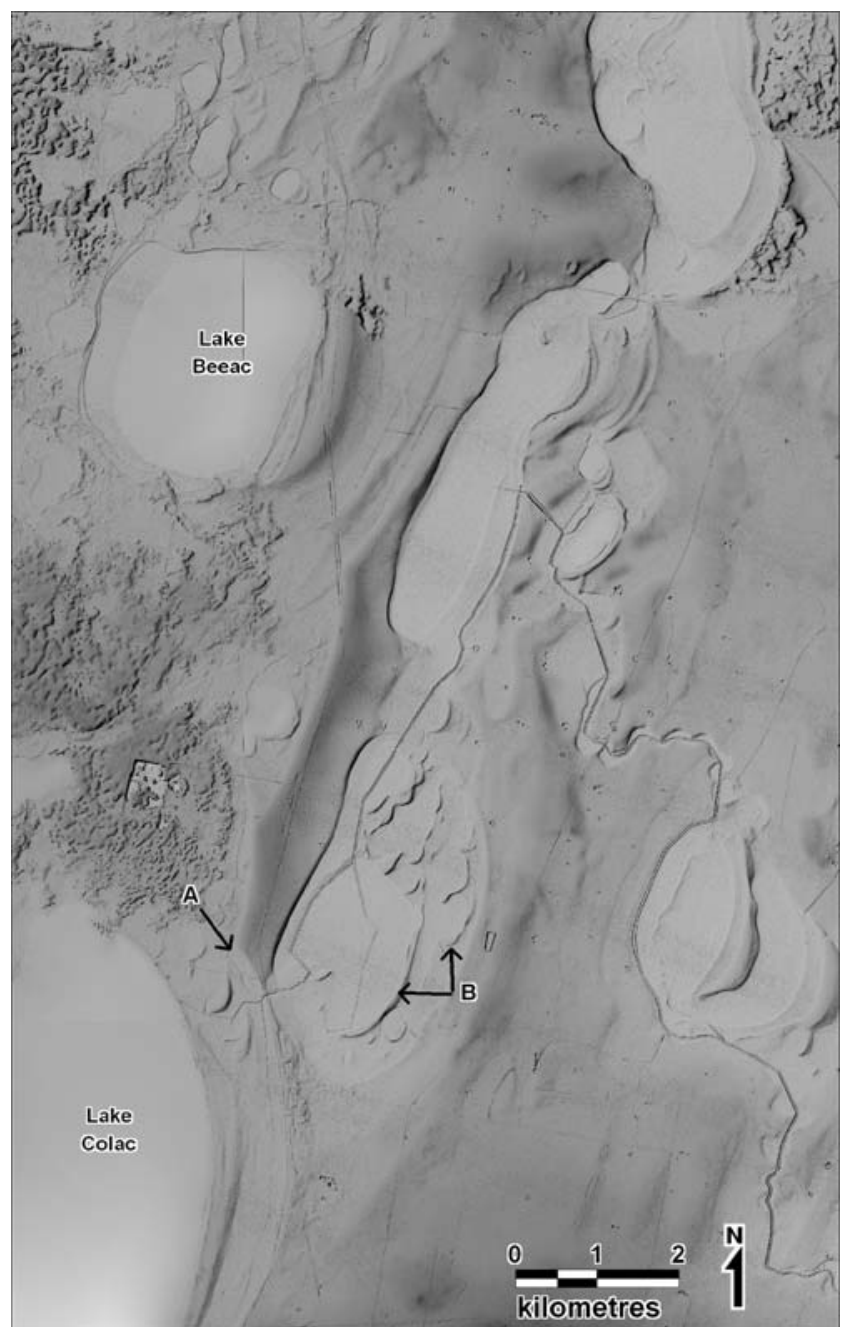

Fig. 3 High-resolution terrain model showing the history of lunette development associated with the hydrologic changes of the lakes ( $A$ truncated lunette indicating increased lake development; $B$ nested lunettes indicating diminishing lake development)

occupation probably declined during the Last Glacial Maximum as drier conditions prevailed.

\section{Salinity in the Holocene (11 ka-Present)}

Warmer and wetter conditions prevailed during the early Holocene as shown by the return to slightly higher lake levels (Dimmer 1992) and more favourable conditions for Aboriginal settlement (McNiven 1998). Archaeological excavations at Lake Colac in which the earliest cultural materials have been dated to around 7,000 years BP are correlated to a sandier horizon in the lunette, indicating more surface flow into the lakes and thus fresher water conditions. Evidence that the population increased significantly during the late Holocene is given by the increase in artefacts and charcoal, dated to around 2,000 years BP, which correlates to higher lake levels in the region. The archaeological evidence of the variations in lake levels and salinity (McNiven 1998) is supported by the palaeoecological and sedimentological research at Lake Keilambete by Mooney (1997), who concluded that there was a period of higher rainfall from $2,000-1,800$ years BP, then decreased rain from 1,750 to 1,425 years BP. Higher rainfalls in the periods between 1,415 and 1,320 years $\mathrm{BP}$ and 1,150 and 800 years BP (which equates with the Medieval Warm Period) are contrasted with a general drying of the climate during the past 130 years of recorded history (Jones et al. 1993).

\section{The early historical record of European settlement}

On the Western Plains of the Corangamite region, McNiven (1998) suggests that the late Holocene settlement patterns were seasonal. People moved out across the landscapes during winter and spring (wet) to take advantage of the diverse food and water supplies, and during summer and autumn (dry) remained close to the permanent fresher water bodies. This pattern of land-use is broadly supported by the early ethno-historical observations, which suggest that the region was a rich diverse area which supported an indigenous population estimated to be between 2,500 and 4,000 persons (Clark 1990). The grassy plains, rivers and wetlands provided an ample supply and variety of food. In particular, shellfish were gathered from the coast; fish and eels were hunted and trapped in the rivers, lakes and estuaries; land mammals and reptiles were hunted on the plains; and birds were taken from the lakes and estuaries.

A record of Aboriginal life is provided by escaped convict William Buckley, who lived with the region's Aboriginal community from 1803 to 1835 (Morgan 1852). The territory of the Wathaurong community with whom Buckley lived extended from the Bellarine Peninsula to Lake Corangamite and from the Otway Ranges to the Central Highlands (Clark 1990). Buckley's account indicates that water quality determined where camps were made and food was sourced. Frequent mention is made of fresh water 'wells', and fresh water, brackish and salt lakes. Buckley refers to the Western Plains as treeless landscapes, and recalls a time camping beside Lake Murdeduke as follows: "There we made our huts with reeds and stones, there being no wood; so bare was it indeed, that we had to go nearly three miles (about 4$5 \mathrm{~km}$ ) for fuel to cook our food with." (Morgan 1852).

This observation of sparsely treed landscapes is confirmed in early records and maps of the Western Plains. Among the earliest historical accounts of the Corangamite landscapes are those of Charles Grimes who surveyed Port Phillip Bay in January 1802 (Fleming 1802) and Matthew Flinders (1814) who described the country around Port Phillip Bay in late April and early May 1802. Grimes records the Werribee Plains as a mosaic of equal parts grass, stone and earth and notes features indicating that water frequently lies on the surface. Flinders traversed the volcanic plains from Corio Bay to the You Yang Range across "....a low plain, where 
water appeared frequently to lodge; it was covered with small bladed grass, but almost destitute of wood, and the soil was clayey and shallow." From the peak he described the country as "...low, grassy, and very slightly covered with wood...", and even on the Bellarine Peninsula "...the wood was so thinly scattered that one might see a considerable distance."

These grassy plains were an attraction to the first pastoral settlers who arrived in 1835 and quickly established sheep runs on the extensive open plains to the west of Geelong and the grassy hills of the Bellarine Peninsula (Todd 1835; Rusden 1872). By 1840, the squatters had ventured over all of the Corangamite region, many parts of which were immediately available for agriculture without the need to remove trees and were well watered with rivers, "...everlasting waterholes, and many fine and valuable springs." (Fyans c. 1853, in Bride 1898).

\section{Historical records of groundwater levels}

Groundwater discharges into many of the shallow saline lakes and wetlands of the Western Plains (Dickinson 1995; Coram et al. 1998; Blackam 1999). Research by Coram et al. (1998) indicate that the groundwater flow to some lakes (e.g. Lake Beeac) is terminal and others (e.g. Lake Murdeduke) are groundwater throughflow lakes. The presence of lunettes, the archaeological sites and the early historic record provide evidence that the groundwater levels were close to the surface of the plains during the wetter periods of the Quaternary. The observations of the early pastoral settlers record water in most of the lakes across the plains, with varying depths related to the climatic conditions of the time (e.g. Fyans c. 1853, in Bride 1898; Bonwick 1858; Brough Smythe 1869; Hebb 1888).

Following the discovery of gold in the northern Corangamite region (Western Uplands) in 1851, in many areas the landscapes were transformed from forests of native vegetation to mining settlements within a decade. Mining Registrar Wood (in Brough Smythe 1869) meticulously documented the earliest mining at Ballarat from 1851 and recorded that many of the earliest mines, some as shallow as 3 to $5 \mathrm{~m}$, were abandoned because of inflows of groundwater. Examples include:

- Golden Point. This is the site of the first discovery of gold at Ballarat. The gold was found in a small watercourse (now Canadian Creek) in late August 1851. By late 1852, shafts were sunk higher up the hill and many were abandoned at $7.5 \mathrm{~m}$ depth (25 feet) because of the groundwater inflows.

- White Flat. Mining commenced in April 1853. Shafts were sunk 3-5 m deep (10-16 feet), but encountered "a great deal of water".

- Canadian Gully. Mining commenced August 1853. Wood noted that a large quantity of groundwater was encountered at a depth of 3-4 m which required three or four men continuously bailing with buckets for mining to continue.
- Red Hill Lead. The mining commenced in shallow ground at the end of 1852, but sinking was very difficult because of "the great quantity of water".

- Eureka Lead. Mining commenced in July 1852. In the vicinity of the Yarrowee Creek, the quantity of water encountered was about $0.25 \mathrm{~L} / \mathrm{s}(200 \mathrm{gal} / \mathrm{h})$ and increased as mining progressed, with some miners bailing with an $82 \mathrm{~L}$ (18 gal) bucket for 6-8 months before they could reach bottom.

- Gravel Pits Lead. Mining commenced in June 1853. In one shaft, the quantity of water was so great that it became impossible to continue sinking until an enginedriven pump was installed. This was one of the first engines on the goldfields.

By 1856 , the deep leads were being worked under the basalt and the volume of water was so immense that the style of claim was changed. One shaft sunk in 1856 through $60 \mathrm{~m}$ (200 feet) of basalt into the Gravel Pit Lead experienced water rising $46 \mathrm{~m}$ (150 feet) up the shaft. The water encountered in the Ballarat West goldfield was on occasion, overwhelming to the miners. New pumps were imported and worked at rates of up to $13 \mathrm{Ml}$ (megalitres)/ day $(2,000 \mathrm{gal} / \mathrm{min})$ until the mines had been dewatered.

Records of the water quality are scarce. Selwyn (1856) reported to the Victorian Legislative Assembly on the potential for fresh water supply by artesian wells. He made the point that surface water runoff is "invariably purer" than groundwater and that "...this appears to be especially the case in Victoria, where ... the very numerous brackish springs which occur in all parts of the Colony where wells have been sunk, and in nearly all formations...". In his report Selwyn gives the assurance that data on water would be included on the geological maps being completed at the time (i.e., the Quarter Sheets of the Geological Survey of Victoria).

Only a dozen Geological Quarter Sheets for the Corangamite region were published, most covering the eastern portion of the Western Plains. The published sheets document 15 wells, 8 springs and 16 waterholes, mostly associated with the pastoral settlements and villages. Information on these features is scarce, but it can be implied by the presence of springs and wells that shallow groundwater was present in some areas of the sparsely populated landscapes of the Corangamite region in 1860 .

During 1870 and 1871 , Ferdinand Krause, the water engineer for Ballarat (and Professor of Geology, Metallurgy and Mining at the Ballarat School of Mines), surveyed and geologically mapped the upper West Moorabool River catchment and the upper Leigh (now Yarrowee) River catchment in the Western Uplands. On the four maps of the proposed water supply area for Ballarat, Krause mapped groundwater discharge in the form of springs and recorded some details of 15 water wells (Table 1). The majority of groundwater levels recorded in 1870 or 1871 are within the range of the average groundwater levels recorded in the 1996-2006 period. 
Table 1 Krause's 1870 and 1871 well depths and water levels compared with the average water levels from 1996-2006

\begin{tabular}{|c|c|c|c|c|c|c|c|c|}
\hline \multirow{2}{*}{\multicolumn{3}{|c|}{$\begin{array}{l}\text { Location details (map grid } \\
\text { of Australia, 1994) }\end{array}$}} & \multicolumn{5}{|c|}{1870 and 1871 geological map data } & \multirow{3}{*}{$\begin{array}{l}\text { Average SWL } \\
\text { 1996-2006 } \\
\text { Metres }\end{array}$} \\
\hline & & & \multirow[t]{2}{*}{ Feature } & \multirow[t]{2}{*}{ Description } & \multicolumn{2}{|c|}{ Well depth } & \multirow{2}{*}{$\begin{array}{l}\text { Standing water } \\
\text { level (SWL) } \\
\text { Metres }\end{array}$} & \\
\hline Zone & Easting & Northing & & & Feet & Metres & & \\
\hline 54 & 763220 & 5840980 & Well & Permanent water. Exceedingly hard & 14 & 4.3 & & 6.7 \\
\hline 54 & 763220 & 5840990 & Well & $\begin{array}{l}\text { Softer water. Liable to run dry in } \\
\text { summer }\end{array}$ & 18 & 5.5 & & 6.7 \\
\hline 54 & 763260 & 5840980 & Well & $\begin{array}{l}\text { Plentiful supply. Tolerably sweet. } \\
\text { Liable to run dry in summer }\end{array}$ & 20 & 6.1 & & 6.6 \\
\hline 54 & 760220 & 5838880 & Well & Water standing at 14 feet $(4.3 \mathrm{~m})$ & 30 & 9.1 & 4.3 & 6.1 \\
\hline 54 & 761220 & 5839180 & Well & Good water & 25 & 7.6 & & 4.2 \\
\hline 54 & 761220 & 5839190 & Well & Brackish water & 22 & 6.7 & & 4.2 \\
\hline 54 & 761220 & 5838380 & Well & Hard water. Standing at 23 feet $(7 \mathrm{~m})$ & 29 & 8.8 & 7.0 & 6.9 \\
\hline 54 & 761320 & 5838280 & Well & $\begin{array}{l}\text { Partly surface water. Standing at } 21 \\
\text { feet }(6.4 \mathrm{~m})\end{array}$ & 35 & 10.7 & 6.4 & 7.2 \\
\hline 54 & 760920 & 5838380 & Well & Good water & 47 & 14.3 & & 6.6 \\
\hline 54 & 762120 & 5837180 & Well & Good water. Standing at 33 feet $(10 \mathrm{~m})$ & 39 & 11.9 & 10.0 & 7.0 \\
\hline 54 & 759620 & 5837180 & Well & Brackish water & Unkr & wn & & 4.5 \\
\hline 55 & 235910 & 5846980 & Well & Good permanent water & 29 & 8.8 & & 9.7 \\
\hline 55 & 236610 & 5836180 & Well & Permanent water & 30 & 9.1 & & 7.2 \\
\hline 55 & 236610 & 5843680 & Well & $\begin{array}{l}\text { Permanent water. Standing at } 18 \text { feet } \\
(5.5 \mathrm{~m})\end{array}$ & & & 5.5 & 9.5 \\
\hline 55 & 236610 & 5843380 & Well & Good water & 32 & 9.75 & & 9.5 \\
\hline 54 & 761420 & 5838780 & Spring & Flowing 468 gallons per hour $(0.6 \mathrm{~L} / \mathrm{s})$ & surfa & & & 5.3 \\
\hline 55 & 236610 & 5844680 & Shaft & Abandoned because of water inflows & 20 & 6.1 & & 9.5 \\
\hline
\end{tabular}

At the time that Krause's maps were completed the catchment was sparsely inhabited and covered in native vegetation. An 1860 survey report records the Moorabool River catchment as "almost entirely wooded" and the Leigh River catchment as "entirely wooded" (Nathan 2004). Recent mapping of native vegetation Ecological Vegetation Community estimates that these pre-settlement (nominated as AD 1750) landscapes were mostly vegetated with plains grassy woodland and herb-rich foothill forest. The plains grassy woodland is described as open eucalypt woodland with approximately 15 large trees (to $15 \mathrm{~m}$ tall) per hectare among grasses and small shrubs. Herb-rich foothill forest is a medium to tall (to $25 \mathrm{~m}$ tall) open forest or woodland with a density of approximately 20 large trees per hectare with a sparse to dense shrub layer over a ground cover of grasses and herbs (DSE 2004).
Much of the forest had been cleared by 1881 when Ballarat Water Commissioner, Mr Thompson, recorded the depth of 74 wells and their groundwater levels in the upper West Moorabool catchment (Nathan 2004). He also recorded 14 surface springs, assumed to be groundwater discharge. Thompson's list records the property owner, but not the precise location of the wells and springs. The water tables in the wells varied from 0.9 to $12.2 \mathrm{~m}$, with an average of $3.2 \mathrm{~m}$. Dunn (1888) also noted that the wells sunk in the basalt in and around the upper West Moorabool water reserve yielded a supply of good quality water, with seasonally fluctuating water tables generally less than $10 \mathrm{~m}$ (30 feet) deep. Although only the approximate locations of the wells are known, the 1881 water table is generally within the range of the average depth to the water table in the 1996-2006 period (Fig. 4),
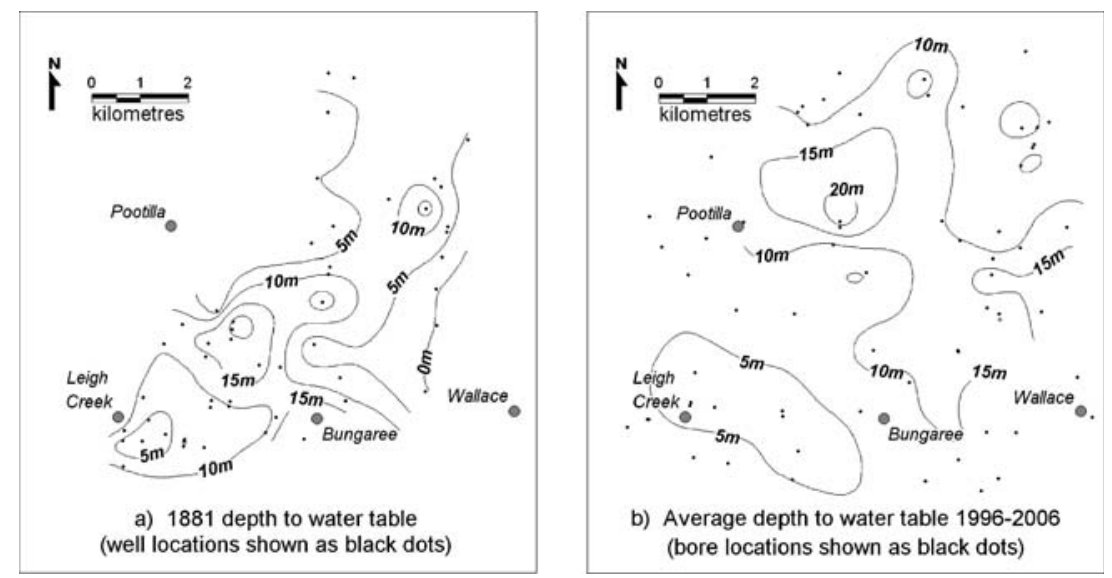

Fig. 4 Depth to water tables in 1881 (a) compared to the average for 1996-2006 (b) in the Upper Moorabool River catchment 
and comparable to those recorded by Krause (1870, 1871; Table 1).

The historical evidence indicates that water tables in the unconfined volcanic aquifer of the West Moorabool River catchment were reasonably shallow even under the forest cover of 1870 , and that subsequent clearing of the landscape for agriculture has not resulted in higher water tables. The current land-use is mixed farming of grazing and cropping, with potatoes as the dominant crop. The groundwater is used for summer irrigation of the crops and the groundwater levels in the unconfined aquifer recover rapidly following drawdown (Evans 2006).

\section{Hydrologic change linked to land-use change}

Within the first three decades of pastoral settlement (from 1835) hydrological changes were observed which were linked to the land-use change. Contrary to the present axiom, the impact of these changes attributed to clearing and agriculture were generally regarded as having a positive impact.

The most commonly made observation on the Western Plains was that the introduction of pastoral agriculture had resulted in compacted soils, increasing runoff (Bonwick 1858; Brough Smythe 1869; Hebb 1888). In the general district around Lake Colac, Hebb (1888) reports that in the 1840 s the soil was "damp, marshy and springy" being "too moist and damp for sheep", such that they had difficulty walking over the "soft and porous" soil, even in the uplands. This observation was made when the pastoral settlement was relatively sparse: in 1845 the (non-indigenous) population of south-western Victoria was approximately 2,998, with 2,286 acres in cultivation and over 1 million sheep.

Bonwick (1858), a school inspector with a great interest in geography and geology, documented the state of the environment during his educational tour of southwestern Victoria in 1857. Bonwick's hydrological observations include numerous references to swamps, waterlogged soils, salt-water and fresh-water lakes, streams and rivers. As a part the narrative account of travel just south of Lake Burrumbeet, Bonwick writes:

I was interested with accounts of the change of climate, as it was said by some, since the occupation of the western country by the Whites. Formerly the drought was greatly to be dreaded. The creeks soon dried up, and the water-holes were few and shallow. Now, water is abundant. Once huge trees grew in hollows in the bed of the stream; now these holes contain twenty and thirty feet of water. The simple truth is, that continual treading of the soil by the hoof of the stock forms a surface, from which the rain water falls into hollows of creeks. Water holes, moreover, are able to retain the precious liquid, better than formerly, because the cattle have by pressure puddled, as it were, the bottom into retentive clay (Bonwick 1858).

This observation is probably made in relation to the water levels and water quality of the lakes, particularly
Lake Burrumbeet. Learmonth (1853, in Bride 1898), the first European settler to visit Lake Burrumbeet, records the water as brackish in August 1837. When the lake was next visited in January 1838 it was "...a few inches deep of intensely salt water" and unrecognisable from the previous visit. Withers (1870) notes that the following year (1839) the lake was dry and remained so for several successive summers.

The influence on the hydrology attributed to first pastoral settlers by Bonwick (1858) accords with an observation made by Brough Smyth (1869), the Secretary for Mines in the Colony of Victoria. The note by Brough Smyth is quoted in its entirety:

Large swamps, which in the memory of settlers have been dry lands for several years in succession, have by tillage and drainage of the adjacent slopes been converted into lakes which have in a brief period increased in depth and area, and inundated large tracts of fertile land. Lake Learmonth, Lake Burrumbeet, and notably Lake Modewarre, are instances of this kind of action.

From records made by the Land Surveyors it appears that in 1841 the bed of Lake Burrumbeet was quite dry and overgrown with fine silky grass, and mussel shells were abundant on the surface. When the lake was full the water was said to be salt. In 1849 there was fresh water to the depth of four and six feet. At the present time there is a great depth of water, and the lake is a conspicuous feature in the landscape; and, when I visited it in October, 1868, there were boats on it, and the proprietor of them told me that he was about to purchase a small steam vessel to ply between the northern and southern shores.

Mr. John Steavenson, the Assistant Commissioner of Roads and Bridges, informs me that, twelve years ago, he was well acquainted with the features of Lake Modewarre. Then the waters were salt-quite unfit for domestic purposes, or even for cattle, and characterised by that peculiar, almost foetid, odour and taste which belong to the waters of many of the salt lakes. Of late years, since the adjoining lands have been cultivated, roads and drains made, and the natural surfaces of the drainage area in many parts denuded of timber and grass, he has tasted the water and found it quite sweet and wholesome. The lake is now from ten to twelve feet above its original level; and many farms have been submerged.

It should be noted that many of the lakes in the Corangamite region, including lakes Burrumbeet and Learmonth, have been dry for the past few years. The low lake levels are attributed to the prolonged period of below average rainfall and human activity such as the extraction of groundwater (Adler and Lawrence 2004).

By 1887, the supply of timber for mining had become an issue in the areas where forests were being rapidly cleared (Langtree 1887). The following year, in a geological report on the Ballarat water supply, Dunn (1888) noted that the flow of springs which had 
continuously supplied excellent water had diminished since the forests had been cleared. These springs were those recorded by Krause in 1871 and Thompson in 1881 and both sources refer to their abundance and suitability as a permanent water supply for Ballarat. Dunn (1888) recommended replanting trees around the heads of the springs and "the vegetation usually found naturally growing along the course of runnels from springs." Ironically, this recommendation - that trees should be planted to restore groundwater discharge - is contrary to that of contemporary salinity management practice which advocates planting trees to reduce groundwater recharge (and therefore, discharge). Nevertheless, it does accord with observations elsewhere in the higher rainfall landscapes of south-west Victoria (Fawcett 2004).

\section{The salinity problem}

The management of salinity in the Corangamite region dates back to the very earliest days of pastoral settlement, when breakwaters were constructed across the Barwon River in 1840 and 1898 to prevent tidal salt reaching the new town of Geelong and secure river water for irrigation (Rosengren 1973). This established the precedent that salinity was primarily a water quality issue in the Corangamite region, and as such was the responsibility of the various water authorities.

An example is given by the 1860 proposal to drain Lake Corangamite and convert it from a saltwater lake to fresh-water storage for irrigation of the plains and as an urban water supply for Colac (Hebb 1888). The idea gained prominence when a series of wet years caused the lake to rise and several adjoining properties were submerged. It was proposed to construct a channel to divert flows from the Woady Yaloak River to the Barwon River via Lake Murdeduke. Remarkably, this idea persisted for a century, and a diversion channel which more or less followed the route proposed in 1860 was constructed following a series of wet years during the 1950 s which caused the lake level to rise and inundate several farm properties. Since the diversion commenced in 1960, the salinity of the lake has dramatically increased and now threatens the ecological values of the asset. It is now proposed to close the diversion channel to restore the lake to its unregulated state (Nicholson et al. 2006).

It was not until the Soil Conservation Authority (SCA) was founded in 1939 that soil salinity emerged as an issue, initially as a process in soil erosion and land degradation. From the outset, soil salinisation was related to land clearance, although the existence of some pre-settlement salinity was acknowledged (Holmes et al. 1939). The relationship of salinity to land clearing had been previously established in the West Australian literature (Wood 1924). Soil salinity in the Corangamite region was first surveyed in 1952 (Cope 1956) and a landmark study published in 1958 by the SCA recorded over 4,000 ha $(10,000$ acres $)$ of salted land in Victoria, including ten locations in the Corangamite region (Cope 1958). This study clearly related salinity to the water-balance and identified rainwater as the main source of salt. It was argued that before European settlement, the rainwater was used by trees where it fell, although it was acknowledged that some saline discharge took place prior to settlement.

During the mid $1970 \mathrm{~s}$, salinity emerged as a separate issue from soil erosion and by 1978 rising groundwater was seen as the dominant cause of salinity (SCA 1978). Salt and land salinisation was attributed to groundwater discharge and the increase in salinity was attributed to the several metres of recharge that had been added to the aquifers since settlement. Hydrogeology replaced agricultural science as the most appropriate research base from which to investigate dryland salting (Jenkin 1983) and observation bores were installed to monitor the rising water tables.

In 1983, the first comprehensive survey of soil salinity was completed for the Corangamite region (Duff 1983). The survey used the presence of several salt-tolerant plant species, aerial photo interpretation, field observations and soil analyses to conclude that approximately $1.2 \%$ of the region is affected by dryland salinity. This investigation distinguished between primary and secondary salinity and made the point that distinction between the two is not clear. The total area affected by both primary (natural) and secondary (induced) soil salinity was 8,298 ha. This detailed investigative study was the first in the region that attempted to relate the salinity to a cause, concluding that rising groundwater levels following the clearing of the native vegetation was to blame. Duff (1983) argued that the ultimate control of secondary soil salinisation is the prevention of groundwater recharge.

The growing concern over salinity resulted in the establishment of the Victorian Government Task Force on salinity in 1985, and the first Victorian Salinity StrategySalt Action-Joint Action-in 1988. The strategy established the Corangamite Salinity Control Region and initiated the development of the first regional salinity strategy for the Corangamite region- "Restoring the Balance"-which was launched in December 1992 (Nicholson et al. 1992). According to the strategy, the single cause of salinity in the Corangamite region is the rising water tables caused by the imbalance in water use following the clearing of native vegetation. The strategy distinguished between local and regional groundwater systems based on the distance from recharge to discharge. Salinity management focussed on recharge control in local groundwater systems.

The implementation of this initial salinity strategy attracted more than AUD\$ 9 million in State and Federal funding and many millions in landholder, industry and community contributions. Key achievements included the establishment of almost 3,500 ha of trees, more than 16,000 ha of perennial pasture and the treatment of 1,130 ha of saline land. Awareness of salinity in rural communities rose from 35 to $65 \%$ of the population, and 10,000 school students were engaged in the Saltwatch program. Many research programs were undertaken and establishment of an extensive monitoring network that 
included 580 bores and 14 surface water monitoring stations.

A comprehensive review of Restoring the Balance in 2002 (Nicholson 2002) concluded that there was little evidence that recharge control had achieved the expected outcomes. The validity of the original simple assumption was questioned and acknowledged that the salinity processes are much more complex than the original 'cause-effect models'. In particular, the understanding of hydrogeology at the scale required to target on-ground works was inadequate, which has implications for the investment of resources in salinity management. Despite the best intentions, few of the salinity works resulted in a reduction in land and water salinisation (although they may have resulted in other positive benefits).

The Victorian Government launched the second generation salinity management framework in August 2000"Restoring our Catchments"-which recognises that, although much has been achieved in the past decade, the 'best practice' agricultural systems in grazing and cropping cannot reduce recharge in high rainfall areas. It proposes that large-scale revegetation may represent the only prospect of halting or reversing water tables in these areas (e.g., much of the Corangamite region).

The Corangamite Salinity Action Plan (Nicholson et al. 2006 ) is the second-generation salinity management program for the Corangamite region, developed in the context of the National Action Plan for Salinity and Water Quality (CoAG 2000), the Victorian Salinity Management Framework (DNRE 2000) and the Corangamite Regional Catchment Strategy 2003-2008 (CCMA 2003). In line with the rationale for investment adopted by the State and regions for natural resource management projects, an asset-based approach was used to identify twelve target locations and priorities for salinity investment. These twelve areas encompass more than $83 \%$ of the salinity in the Corangamite region, including $87 \%$ of the saline wetlands and $72 \%$ of the saline land.

\section{Current condition}

Salinity appears in the Corangamite Region as either saline land, saline wetlands or as changes in the salinity of surface water. Of the 63,000 ha of mapped salinity in the Corangamite region, $73 \%$ occurs as semi-permanent or permanently saline wetlands and the remaining $27 \%$ as land salinity.

However, land salting is the most obvious manifestation of salinity in the Corangamite Region. Assembling and rationalising all previous mapping indicates there are 17,250 ha of land salting, occurring at 1,500 locations in the landscape. This estimate is confounded by the presence of both primary (natural) and secondary (induced) salinity. In some locations, the separation between natural and induced land salting has been made at the time of mapping on the basis of the indicator plants present. However, in many other areas, the distinction is less clear. Based on the details provided in the original mapping and the historical record of salinity at the site, it is estimated that just over half the mapped land salinity is primary in origin (Fig. 5). If the integrity of this natural salting is intact, these areas need to be viewed as environmental assets.

\section{Current trends in land salinity}

The area of land salinised in the Corangamite region has been assessed at various times over the past 30 years. A review of the most recent salinity mapping indicates that the area of land salinised is increasing in some areas of the Corangamite region.

A reassessment of $15 \%$ of the previously mapped land salinity was undertaken by the Department of Natural Resources and Environment (Gardiner 2001). The project mapped 156 sites, of which 133 were previously mapped and 23 were new additions to the database. The 156 sites represented $17 \%$ of the land salinity sites mapped at the time. The review found that the 2006.6 ha of land salinity previously mapped had increased $11 \%$ to cover 2242.9 ha. The new additions to the mapped land salinity covered 137.4 ha in the regions mapped. The severity of the land salinity at the reassessed sites had changed considerably, with a $36 \%$ increase in severity 1 (low salinity), $24 \%$ decrease in severity 2 and a $0.9 \%$ decrease in severity 3 (high salinity).

Gardiner's survey was the first attempt to achieve a statistically significant reassessment of land salinity in the Corangamite region. Although the results are valuable, the timing of the survey-January to March 2001-was not ideal for the accurate identification of saline vegetation indicators and came at a time when rainfall had been below average for the antecedent 5 years. This highlights the fact that visual monitoring of land salinity is only useful as an indicative measure.

In August 2004, Primary Industries Research Victoria (PIRVic) reported on the re-assessment of six discharge

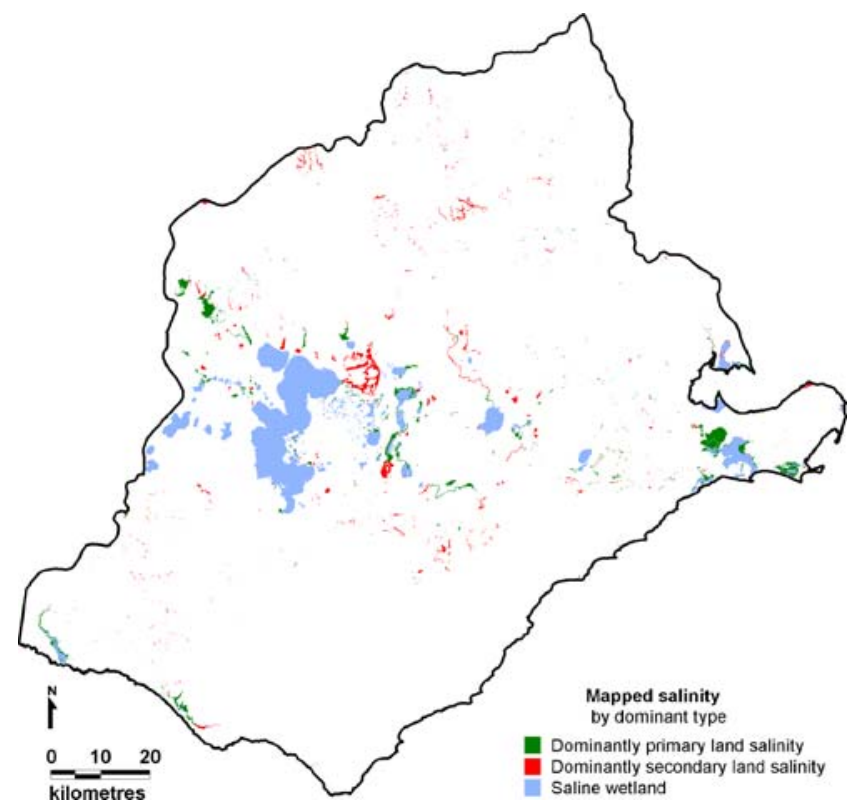

Fig. 5 Distribution of salinity in the Corangamite region 
sites in the Corangamite region which are part of the Victorian Dryland Salinity Monitoring Network (Clark and Hekmeijer 2004). A summary of their findings are tabulated in Table 2.

The results of the monitoring indicate the difficulty in linking cause and effect at an individual site. As an example, at the Gerangamete agroforestry site, recharge control treatment (planting of tree belts) commenced in 1993. Since that time, the area of land affected by salinity has increased by at least $7 \%$ and the water tables have dropped 0.5 to $1.5 \mathrm{~m}$. During the same period, at the control site at Gerangamete, where no treatment has been undertaken, the area of land affected by salinity has decreased $25 \%$ and the groundwater levels have remained relatively stable.

Similarly, at the Pittong monitoring site, the area of land affected by salinity has increased $8 \%$ over the period from 1996 to 2000, while the groundwater levels had dropped slightly over the same period. This phenomenon has been verified by the landholders in the area who have witnessed new salinity discharge sites emerge in the past 5 years.

In the period from October to December 2005, approximately 1,150 potential saline sites in the designated urban growth areas of four municipalities in the Corangamite region were examined by the Department of Primary Industries (DPI 2006). Of these, 558 sites totalling $3,920.5$ ha were accurately mapped by 16 individual assessors, each using handheld GPS. The mapping was based solely on vegetation indicators, using one of the standard salinity mapping methods developed by PIRVic (Clark and Allan 2005). Parameters recorded were the severity rating (i.e. the percentage of the site affected by low, medium, high or severe salinity) and the type of salinity (natural, induced or a combination of both). Additional mapping was completed using traditional stereo photogrammetry of recent aerial photos.

In total, 4,823.9 ha were mapped as salt affected within the 22 urban growth areas. This represented 585 sites of which 350 were new or previously unmapped sites and a $40 \%$ increase from the previous assessment. The 2005 mapping categorised $12 \%$ of the area as secondary salinity, $21 \%$ as of primary salinity and $67 \%$ as combined primary and secondary salinity. Only $5 \%$ of the areas were highly saline, with $25 \%$ moderate and $70 \%$ slightly saline (DPI 2006).

\section{Current trends in stream salinity}

Trend analysis on all rivers and streams with a record of salinity measurement was completed in 2003 for the development of the Corangamite Salinity Action Plan (Dahlhaus et al. 2005). A semi-parametric statistical method (Morton 1997) based on the generalised additive model (GAM) approach (Hastie and Tibshirani 1990) was used to obtain stream salinity trends that are independent of fluctuations in flow and season, and hence are indicative of the impacts of saline groundwater inflows caused by catchment salinisation. Although the method corrects for flow and seasonal effects, the analyses do not account for longer-term climate variations such as a run of wet years or a run of dry years.

Electrical conductivity (EC), used as a surrogate measure for water salinity, has been regularly measured at some stream gauging stations in the Corangamite region for about 30 years. The length of record varies and several stations no longer monitor EC, nevertheless all available EC data were used to determine the trends. The results (Table 3; Fig. 6) show a wide variation in water salinity trends over the gauging period. Considering those stations with a longer-term record (greater than 10 years) and trends with statistical significance, the Moorabool River shows the greatest increase, with the end-of-valley salinity having almost doubled over the past 30 years. The linear trend of the mean monthly EC measured at the Batesford gauge for the 1976 to 2005 period is $23.7 \pm 6.0 \mu \mathrm{S} / \mathrm{cm} /$ year (Table 3). Extrapolating the non-linear trend (Fig. 7), the EC will continue to rise to a projected mean EC of between 2,320 and $2,404 \mu \mathrm{S} / \mathrm{cm}$ by 2012 .

By contrast, the EC trends in the Barwon River show that the end-of-valley salinity has decreased over the past 30 years. Extrapolating the non-linear trend indicates that the mean EC will continue to decline (Fig. 7). The causes for these trends are difficult to ascertain, as they are influenced by the regulation of the rivers, the diversion of surface water and groundwater from the streams and the harvesting of surface water in farm dams.

\section{Discussion}

This review of the geomorphological and historical evidence supports the premise that shallow groundwater and salinity have been present in the Corangamite region

Table 2 Summary of discharge monitoring at the six State discharge monitoring reference sites (summarised from Clark and Hekmeijer 2004)

\begin{tabular}{|c|c|c|c|c|c|c|}
\hline Location & Beeac & $\begin{array}{l}\text { Gerangamete } \\
\text { agroforestry }\end{array}$ & $\begin{array}{l}\text { Gerangamete } \\
\text { control }\end{array}$ & Moriac & Pittong & Wingeel \\
\hline Year established & 1996 & 1994 & 1994 & 1995 & 1996 & 1995 \\
\hline Year reassessed & 2000 & 1999 & 1999 & 2000 & 2000 & 1999 \\
\hline $\begin{array}{l}\text { Change in total } \\
\text { salt-affected area }\end{array}$ & $13 \%$ decrease & $7 \%$ increase & $25 \%$ decrease & $7 \%$ decrease & $8 \%$ increase & $18 \%$ decrease \\
\hline $\begin{array}{l}\text { Change in groundwater } \\
\text { levels }\end{array}$ & $1 \mathrm{~m}$ lower & $0.5-1.5 \mathrm{~m}$ lower & Stable & $0.6 \mathrm{~m}$ lower & Slightly lower & $0.4 \mathrm{~m}$ lower \\
\hline
\end{tabular}


Table 3 EC trends in the Corangamite region waterways

\begin{tabular}{|c|c|c|c|c|c|c|}
\hline \multirow[t]{2}{*}{ Gauge No. } & \multirow[t]{2}{*}{ Station name } & \multicolumn{2}{|c|}{ EC records } & \multirow{2}{*}{$\frac{\text { Salt load }}{\text { Tonnes/day }}$} & \multirow{2}{*}{$\frac{\text { Mean EC }}{\mu \mathrm{S} / \mathrm{cm}}$} & \multirow{2}{*}{$\frac{\text { Linear EC trend }}{\mu \mathrm{S} / \mathrm{cm} / \text { year }}$} \\
\hline & & Start & End & & & \\
\hline 232202 & Moorabool River at Batesford & Nov-76 & Feb-05 & 81 & 1,521 & $23.7 \pm 6 . .0$ \\
\hline 232204 & Moorabool River at Morrisons & Nov-76 & Jun-01 & 44 & 643 & $-0.8 \pm 2.6$ \\
\hline 232210 & Moorabool River West Branch at Lal Lal & Dec-76 & Feb-05 & 5 & 421 & $1.9 \pm 1.0$ \\
\hline 232211 & Moorabool River West Branch at Mount Doran & Nov-76 & Jul-90 & 21 & 473 & $10.9 \pm 2.7$ \\
\hline 233200 & Barwon River at Pollocksford & Nov-76 & Feb-05 & 495 & 1,991 & $-31.8 \pm 8.3$ \\
\hline 233211 & Birregurra Creek at Ricketts Marsh & Oct-76 & Dec-04 & 294 & 10,429 & $-175.1 \pm 112.2$ \\
\hline 233214 & Barwon River East Branch at Forrest & Mar-78 & Aug-01 & 3 & 150 & $-0.1 \pm 0.3$ \\
\hline 233215 & Leigh River at Mount Mercer & Nov-76 & Sep-01 & 82 & 1,146 & $-1.4 \pm 3.8$ \\
\hline 233218 & Barwon River at Inverleigh & Oct-76 & Jun-01 & 330 & 2,196 & $-21.7 \pm 13.9$ \\
\hline 233223 & Warrambine Creek at Warrambine & Nov-76 & Jan-84 & 10 & 4,287 & $104.2 \pm 236.4$ \\
\hline 233224 & Barwon River at Ricketts Marsh & Oct-76 & Jul-01 & 99 & 897 & $-2.2 \pm 5.5$ \\
\hline 233228 & Boundary Creek at Yeodene & Jun-85 & Aug-01 & 4 & 597 & $12.8 \pm 5.4$ \\
\hline 234200 & Woady Yaloak River at Pitfield & Nov-76 & Jul-90 & 49 & 2,138 & $-35.4 \pm 35.1$ \\
\hline 234201 & Woady Yaloak River at Cressy (Yarima) & Nov-76 & Feb-05 & 242 & 5,265 & $3.4 \pm 23.7$ \\
\hline 234203 & Pirron Yallock Creek at Pirron Yallock & Jan-77 & Feb-05 & 35 & 1,221 & $10.3 \pm 7.4$ \\
\hline 235202 & Gellibrand River at Upper Gellibrand & Dec-76 & Jul-89 & 8 & 139 & $0.4 \pm 0.7$ \\
\hline 235203 & Curdies River at Curdie & Jan-77 & Oct-93 & 183 & 1,194 & $5.9 \pm 7.6$ \\
\hline 235204 & Little Aire Creek at Beech Forest & Jan-77 & Aug-01 & 2 & 98 & $-0.3 \pm 0.2$ \\
\hline 235205 & Arkins Creek West Branch at Wyelangta & May-78 & Aug-01 & 1 & 100 & $-0.1 \pm 0.3$ \\
\hline 235208 & Gellibrand River at Carlisle & Dec-76 & Feb-88 & 62 & 200 & $0.0 \pm 1.3$ \\
\hline 235209 & Aire River at Beech Forest & Mar-91 & Aug-01 & 3 & 117 & $0.0 \pm 0.6$ \\
\hline 235210 & Lardner Creek at Gellibrand & Dec-76 & Jun-01 & 6 & 154 & $0.2 \pm 0.9$ \\
\hline 235212 & Chapple Creek at Chapple Vale & Dec-76 & Jun-88 & 4 & 199 & $0.4 \pm 1.3$ \\
\hline 235216 & Cumberland River at Lorne & Oct-76 & Jun-01 & 1 & 18 & $-0.1 \pm 0.2$ \\
\hline 235219 & Aire River at Wyelangta & Nov-76 & Jun-88 & 16 & 125 & $-0.5 \pm 0.7$ \\
\hline 235222 & Anglesea River (Salt Creek) at Anglesea & Aug-76 & Nov-82 & 2 & 800 & $160.8 \pm 90.0$ \\
\hline 235223 & Scotts Creek at Scotts Creek & Jan-77 & May-87 & 18 & 1,927 & $-0.8 \pm 36.5$ \\
\hline 235224 & Gellibrand River at Burrupa & Dec-76 & Jul-01 & 109 & 273 & $-0.4 \pm 0.7$ \\
\hline 235226 & St George River at Allenvale & Nov-76 & Jun-88 & 2 & 186 & $0.3 \pm 1.4$ \\
\hline 235227 & Gellibrand River at Bunkers Hill & Dec-76 & Aug-01 & 37 & 221 & $-0.6 \pm 0.6$ \\
\hline 235229 & Ford River at Glenaire & Nov-76 & May-87 & 8 & 169 & $-1.0 \pm 1.0$ \\
\hline 235232 & Painkalac Creek at Painkalac Creek Dam & Oct-76 & Apr-87 & 2 & 403 & $-19.6 \pm 8.3$ \\
\hline 235233 & Barham River East Branch at Apollo Bay & Nov-77 & Jul-90 & 9 & 201 & $0.6 \pm 0.9$ \\
\hline 235234 & Love Creek at Gellibrand & May-79 & Jun-01 & 5 & 445 & $-0.8 \pm 3.0$ \\
\hline 235237 & Scotts Creek at Curdie (Digneys Bridge) & Jul-88 & Jan-01 & 162 & 1,468 & $21.7 \pm 21.8$ \\
\hline 235239 & Ten Mile Creek at Kawarren & May-85 & Jan-94 & 1 & 429 & $-12.2 \pm 6.8$ \\
\hline 235240 & Yahoo Creek at Kawarren & May-85 & Jan-94 & 1 & 439 & $-6.8 \pm 5.3$ \\
\hline 235241 & Porcupine Creek at Kawarren & May-86 & Jan-94 & 3 & 334 & $-8.5 \pm 6.4$ \\
\hline
\end{tabular}

The linear trends are shown with their standard errors ( $95 \%$ confidence level) which are adjusted for the degree of autocorrelation in the GAM analysis (Morton 1997). Locations are shown in Fig. 6

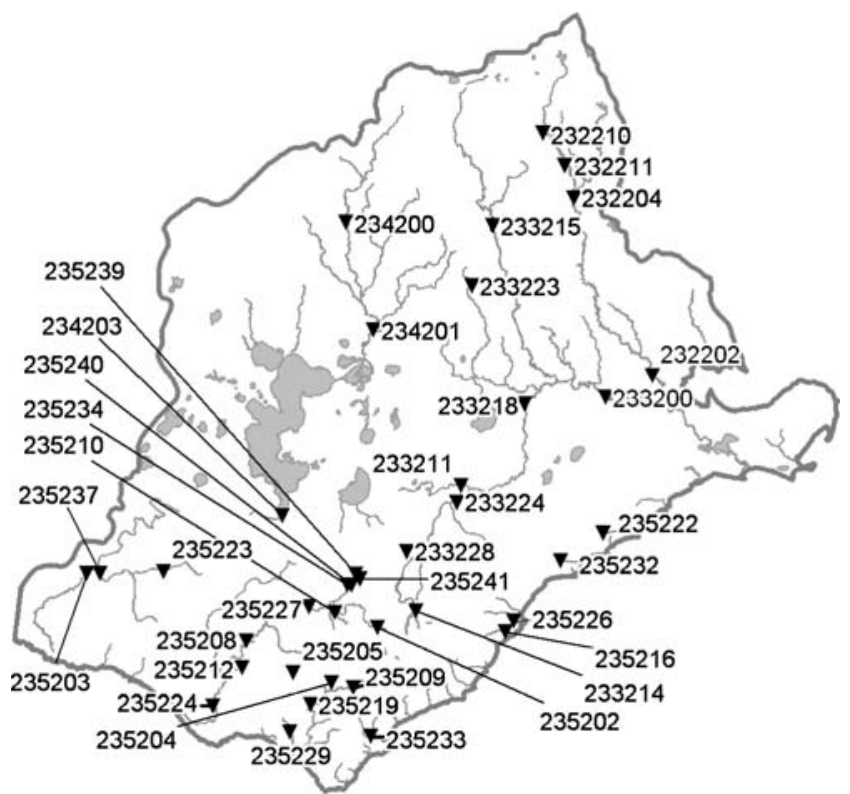

Fig. 6 Locations of the gauging stations listed in Table 3 landscapes for centuries. In some areas (e.g., the volcanic landscapes of the Western Uplands and the Western Plains) the depth of the groundwater below the surface has remained relatively unchanged over the past 200 years, despite the widespread land-use change.

With the onset of pastoral settlement on the Western Plains in the late 1830s the change in land-use was a transition from native grasslands to pastures and crops. The extent of natural salting in the landscape is impossible to accurately quantify because in many situations the naturally occurring salinity has been modified by the postsettlement changes to the environment. However, there is sufficient geomorphic, historical and field mapping evidence that both saline wetlands and land salinity were present before European settlement and these saline areas were diverse and extensive throughout the region.

If the integrity of this natural salting is intact, these areas need to be viewed as environmental assets. Most of the larger saline wetlands are already classed as international environmental assets, and many of the smaller ones are protected under municipal planning overlays. The 

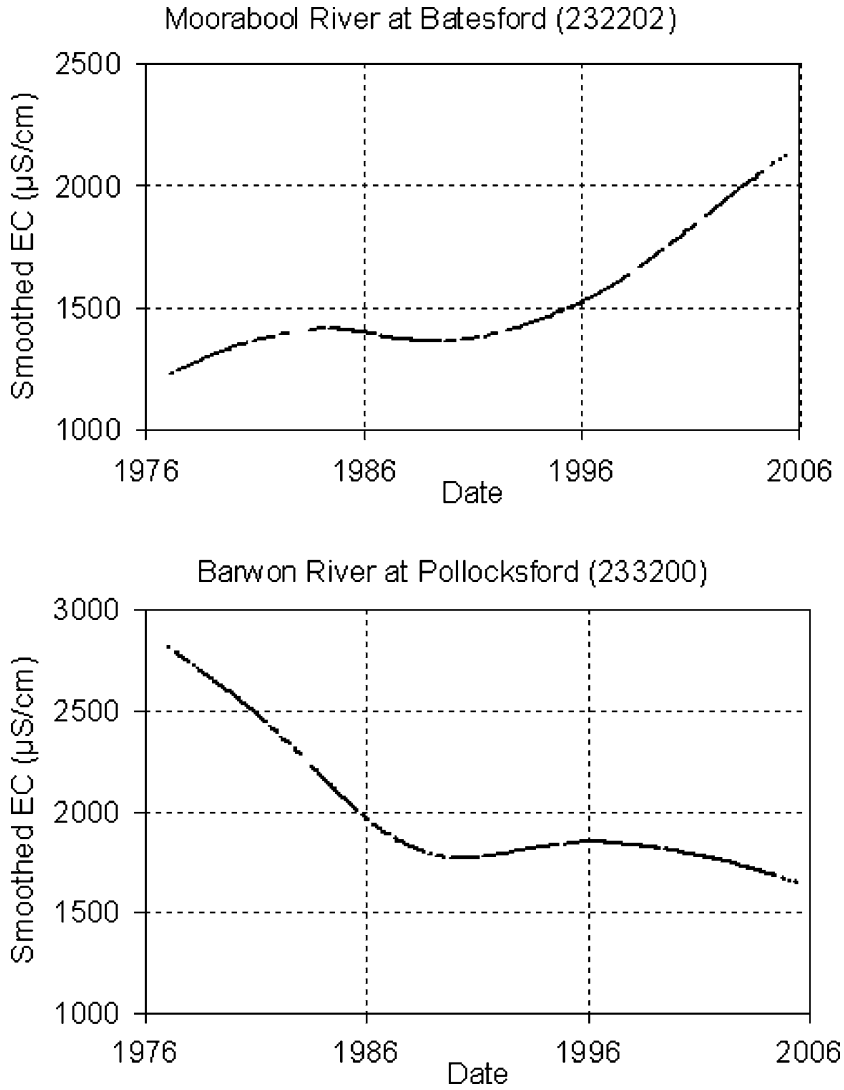

Fig. 7 End of valley trends in stream salinity for the Moorabool River and Barwon River. These non-linear smoothed trends are derived from the GAM analysis of the EC data for the periods listed in Table 3

biodiversity value of the primary land salinity has only recently been recognised and some sites have rare halophytic plants present. In the areas mapped as primary salinity, $12 \%$ has an ecological vegetation community with bioregional conservation status classified as endangered, and $6.1 \%$ classified as vulnerable. By contrast, in the areas mapped as secondary salinity, only $0.4 \%$ of the vegetation is classed as endangered and $0.3 \%$ as vulnerable. The saline wetlands have $8.9 \%$ of their ecological vegetation community classified as endangered bioregional conservation status.

Nearly all of the permanent wetlands are believed to receive groundwater discharge, such that they vary in their salinity range from brackish to hypersaline. The geomorphic evidence, archaeological research and earliest historical records indicate that climate is the dominant control on lake levels. This conclusion was also reached by Jones (1995) who used a water balance approach to show that the falling lake levels in two closed lakes (in volcanic craters) in the region was due to the changed precipitation to evaporation ratio over the past century. Salinity management of these assets relies on maintaining groundwater levels and in at least one case, groundwater extraction has been linked to the drying of saline lakes in the region (Adler and Lawrence 2004).

Nearly $77 \%$ of the mapped primary salinity and $74 \%$ of the secondary salinity occurs in areas mapped as local groundwater flow systems. The high percentage of primary salinity in local systems is counterintuitive to the argument that local systems are the most responsive to land-use change. This implies that (1) saline groundwater discharge was present in these areas before widespread land-use change, or (2) the saline discharge emanates from underlying regional groundwater systems, or (3) a substantial proportion of the salinity and/or groundwater flow systems are incorrectly mapped.

A closer examination of the data reveals that nearly all of the primary salinity in local groundwater flow systems occurs in areas where unconsolidated Quaternary sediments overlie regional groundwater flow systems of the Western Plains. While the relatively thin veneer of Quaternary sediments is hydrologically responsive to land-use, the major influence on salinity is the underlying regional groundwater discharge, which has remained relatively unchanged with the change in land use from the native grasslands to pastures and crops.

In the Western Uplands, the land-use change was more dramatic, particularly during the three decades following the discovery of gold. Yet historical records show that earliest recorded groundwater levels were within the range of the present-day levels. One explanation for this observation is that the groundwater systems in these areas are regulated by the rate of discharge, with average annual recharge in excess of discharge. These discharge-driven groundwater systems may have been relatively full for centuries.

Although land salinity has been present in the Corangamite region since the beginnings of pastoral settlement, it was not documented as an issue until over a century later. This may be due in part to the increased economic impacts of salinity as the size of land holdings decreased, particularly with the Soldier Settlement and Closer Settlement schemes following the 1914-1918 war (Nathan 2000). However, it is likely that the widespread clearing of the native vegetation has induced a hydrological response in some groundwater systems in the region, causing secondary salinity to develop. The region-wide trends in water tables measured in the salinity monitoring bores suggest that, in most locations, equilibrium may have been reached. This argument is supported by the observation that many discharge areas have remained static or reduced in size.

Nevertheless, the data from the most recent monitoring and mapping indicate that land salinity in some locations has expanded during the past decade. In these areas, the falling trend in groundwater levels suggests that other factors such as changes to soil waterlogging and regolith hydrology are implicated in the spread of salinity (Dahlhaus and MacEwan 1997).

\section{Conclusions}

Salinity has been an episodic feature of the Corangamite region throughout the Quaternary. The salinity of the lakes on the volcanic plains has varied with climate change and is recorded in the geomorphology, especially the lunettes. The Aboriginal archaeological evidence supports varia- 
tions in salinity during the aboriginal occupation of the Corangamite landscapes during the Pleistocene and Holocene.

The earliest historical accounts of the landscape record shallow water tables and saline lakes and drainage lines as existing features of the landscape. There is no recorded evidence found which supports significant rises in groundwater following widespread land-use change. From the earliest recorded history, observed changes to the landscape hydrology were linked to anthropogenic causes, but they are contrary to the current axiom.

This review adds to the growing body of evidence that rising water tables are not the single cause of salinity in many of Australia's landscapes (Dahlhaus et al. 2000; Wagner 2005; Fawcett 2004; Bann and Field 2006). The increasing salinity which threatens the Corangamite region's assets cannot be universally equated to rising groundwater following European settlement. Land-use change was not a single 'event' but is a continuum, with many landscapes undergoing constant but relatively minor change (native grasslands replaced with exotic grasslands or crops; or native forests replaced with regrowth or plantation forests).

In ignorance of the context provided by researching beyond the hydrogeologic evidence, the traditional salinity management has focussed on using trees to lower the shallow water tables. However, this review has shown that in many areas salinity is an inherent component of the region's landscapes, and sustains world class environmental assets (Ramsar wetlands). Maintaining appropriate salinity levels is vital for their ecological health. Managing salinity by lowering the groundwater levels is contradictory to the geomorphic and historical evidence, and may threaten environmental assets. Determining the most appropriate salinity management in the Corangamite region requires assessing the risk to each individual asset.

Acknowledgements The Corangamite Catchment Management Authority provided the funding for this research. The work contributes towards PD's PhD studies partly funded through an Australian Postgraduate Award. Thanks to Dr Erica Nathan who provided some of the historical references.

\section{References}

Adler R, Lawrence CR (2004) The drying of the Red Rocks Lakes complex, Australia, and its implications for groundwater management. Groundwater Flow Understanding from Local to Regional Scales, Proceedings of the XXXIII Congress IAH and 7th Congress ALHSUD, Zacatecas, Mexico, October 2004 (extended abstract T1-54 on CD)

Bann GR, Field JB (2006) Dryland salinity in south east Australia: Which scenario makes more sense? Extended Abstract, Australian Earth Sciences Convention 2006. GSA 18th Australian Geological Convention and AESC 18th International Geophysical Conference and Exhibition, Melbourne, 2-6 July 2006 (on CD)

Blackam MJ (1999) Numerical modelling of groundwater flow systems in the Lake Corangamite- Barwon River region. Thesis, University of Ballarat, Australia

Bonwick J (1858) Western Victoria, its geography, geology and social condition. In: Sayers CE (ed) 1967 edn., Heinemann, Melbourne
Bowler JM (1983) Lunettes as indices of hydrologic change: a review of Australian evidence. Proc R Soc Vic 95:147-168

Bride TF (1898) Letters from Victorian pioneers. In: Sayers CE (ed) 1967 edn., Heinemann, Melbourne

Brough Smyth R (1869) The Gold Fields and Mineral Districts of Victoria. In: Blainey G (ed) 1980 edn., Queensberry Hill, Carlton, Victoria

CCMA (2003) Corangamite Regional Catchment Strategy 20032008. Corangamite Catchment Management Authority, Colac, Victoria, Australia

Clark ID (1990) Aboriginal languages and clans: an historical atlas of western and central Victoria, 1800-1900. Monash Publ. in Geography No. 37. Monash University, Clayton, Australia

Clark RM, Allan MJ (2005) The salinity monitoring site network in Victoria: standards and procedures. Report, Primary Industries Research, Victoria, Australia

Clark RM, Hekmeijer P (2004) Victorian salinity monitoring: reassessment of six reference discharge monitoring sites in the Corangamite region. Centre for Land Protection Research Report 43, Primary Industries Research, Victoria

CoAG (2000) Our vital resources: a national action plan for salinity and water quality. Council of Australian Governments, 3rd November 2000. Commonwealth of Australia. Available online at: http://www.napswq.gov.au/. Cited 8 September 2006

Cope F (1956) Salting in Victorian Catchments. MSc Thesis, The University of Melbourne, Australia

Cope F (1958) Catchment Salting in Victoria. Soil Conservation Authority of Victoria, Kew, Melbourne

Coram JE, Weaver TR, Lawrence CR (1998) Groundwater-surface water interactions around shallow lakes of the Western District Plains, Victoria, Australia. Groundwater: Sustainable Solutions, Proceedings of the International Groundwater Conference 1998, University of Melbourne, Melbourne, Australia, 8-13 February, 1998, IAH Australia, Perth, pp 119-124

Dahlhaus PG (2004) Characterising groundwater flow systems for salinity management in the Corangamite Region, Australia. Groundwater Flow Understanding from Local to Regional Scales, Proceedings of the XXXIII Congress IAH and 7th Congress ALHSUD, Zacatecas, Mexico, October 2004 (extended abstract $\mathrm{T} 1-30$ on $\mathrm{CD}$ )

Dahlhaus PG, MacEwan RJ (1997) Dryland salinity in south west Victoria: challenging the myth. In: McNally GH (ed) Collected case studies in engineering geology, hydrogeology and environmental geology, 3rd Series, Environmental, Engineering and Hydrogeology Specialist Group of Geological Society of Australia, Sydney, pp 165-180

Dahlhaus PG, MacEwan RJ, Nathan EL, Morand VJ (2000) Salinity on the southeastern Dundas Tableland, Victoria. Aust J Earth Sci 47/1:3-11

Dahlhaus PG, Heislers DS, Dyson PR (2002) Groundwater flow systems. Consulting report CCMA 02/02, Corangamite Catchment Management Authority, Colac, Victoria

Dahlhaus PG, Smitt CM, Cox JW, Nicholson C (2005) Corangamite Salinity Action Plan: setting resource condition targets. Background report 9, Corangamite Salinity Action Plan, Corangamite Catchment Management Authority, Colac, Victoria

Dickinson CG (1995) Numerical modelling of groundwater systems around Lake Corangamite. BSc Thesis, University of Ballarat, Australia

Dimmer LL (1992) Geology and evolution of lacustrine sediments within the Newer Volcanics, Beeac, Western Plains District, Victoria. BSc Thesis, Australian National University, Australia

DNRE (2000) Victoria's salinity management framework: restoring our catchments. August 2000. Department of Natural Resources and Environment, Victoria

DPI (2006) Salinity discharge mapping: across priority areas in the Surfcoast, Colac Otway, Golden Plains and Corangamite Shires. Department of Primary Industries, Victoria, May 2006

DSE (2004) EVC benchmarks: Central Victorian Uplands bioregion. Department of Sustainability and Environment, Victoria. Available Online at http://www.dse.vic.gov.au/. Cited 26 September 2006 
Duff JS (1983) Soil salting in the Lake Corangamite region of south western Victoria. MSc Thesis, The University of Melbourne, Australia

Dunn EJ (1888) Report on the Ballarat and Ballarat East Water Reserves. Reports of the Mining Registrars Quarter ended 30th June, 1888, Victorian Government, Melbourne

Edwards J, Leonard JG, Pettifer GR, McDonald PA (1996) Colac 1:250 000 map geological report. Geological Survey Report 98, Department of Natural Resources and Environment, Melbourne

Evans TJ (2006) Geology and groundwater flow systems in the West Moorabool River catchment and their relation to river salinity. MSc Thesis, University of Technology, Sydney

Fawcett J (2004) Processes and implications of scald formation on the Eastern Dundas Tableland: a case study. PhD Thesis, The University of Melbourne

Fleming J (1802) Journal of the Explorations of Charles Grimes. In: 1984 edn., Queensberry Hill, Melbourne

Flinders M (1814) A voyage to Terra Australis. In: Flannery T (ed) Abridged 2000 edn., Text Publishing, Melbourne, Australia

Gardiner B (2001) Salinity discharge mapping in the Corangamite region. Report, Department of Primary Industries, Colac, Victoria

George R, McFarlane D, Nulsen R (1997) Salinity threatens the viability of agriculture and ecosystems in Western Australia. Hydrogeol J 5/1:6-21

Ghassemi F, Jakeman AJ, Nix HA (1995) Salinisation of land and water resources: human causes, extent, management and case studies. UNSW, Sydney

Hastie TJ, Tibshirani RJ (1990) Generalized additive models. Chapman and Hall, New York

Hebb I (1888) The history of Colac and District. In: 1970 edn. Hawthorn, Melbourne

Holmes L, Leeper G, Nicolls K (1939) Survey of the country around Berwick. Proc R Soc Vic (New series) 52/1:177-238

Jenkin JJ (1983) Dryland salinity symposium: introduction. Proc R Soc Vic 95:101-102

Jones RN (1995) Modelling hydrologic and climatic controls of closed lakes, Western Victoria. PhD Thesis, The University of Melbourne, Australia

Jones RN, Bowler JM, MacMahon TA (1993) Modelling water budgets of closed lakes, western Victoria. Quat Australasia Pap $11: 50-60$

Joyce EB, Webb JA, Dahlhaus PG, Grimes K, Hill SM, Kotsonis A, Martin J, Mitchell M, Neilson JL, Orr M, Peterson JA, Rosengren N, Rowan JN, Rowe RK, Sargeant I, Stone T, Smith BL, White S (with material by the late J.J. Jenkin) (2003) Geomorphology. In: Birch WD (ed) Geology of Victoria, Geological Society of Australia Special Publication 23. Geological Society of Australia, Victoria, pp 533-562

Krause FM $(1870,1871)$ Geological survey of country in the parishes of Bungaree, Warrenheip and Dean. Map Sheets 1, 3, 4 and 5. Ballarat and Ballarat East Water Supply Committee, Ballarat, Australia

Langtree CW (1887) Timber supply for the goldfields. Reports of the Mining Registrars for the Quarter Ended 30 June 1887, Appendix A, Department of Mines and Water Supply, Victoria, pp 69-70

McNiven IJ (1998) Aboriginal settlement of the saline lake and volcanic landscapes of Corangamite Basin, western Victoria. Artefact 21:63-94

Mooney SD (1997) A fine-resolution palaeoclimatic reconstruction of the last 2000years, from Lake Keilambete, southeastern Australia. Holocene 7:139-149
Morgan J (1852) The life and adventures of William Buckley. In: Sayers CE (ed) 1967 edn., Heinemann, Melbourne

Morton R (1997) Semi-parametric models for trends in stream salinity. Report Number CMIS 97/71 CSIRO Mathematical and Information Sciences, Canberra, Australia

Mulvaney DJ, Kamminga J (1999) Prehistory of Australia. Allen and Unwin, St. Leonards, Australia

Nathan EL (2000) Giving salt some history, and history some salt: dryland salinity and the Dundas Tableland. Aust Hist Stud 31/ $115: 222-236$

Nathan EL (2004) Lost waters of West Moorabool: a history of a community and its catchment. $\mathrm{PhD}$ Thesis, The University of Melbourne, Australia

Nicholson C (2002) Review of the Corangamite salinity strategy "Restoring the balance". Consulting report by Nicon Rural Services, Corangamite Catchment Management Authority, Colac, Victoria

Nicholson C, Straw W, Conroy F, MacEwan RJ (1992) Restoring the balance: dryland salinity strategy for the Corangamite Salinity Region. Corangamite Salinity Forum, Colac, Victoria

Nicholson C, Dahlhaus PG, Anderson G, Kelliher C, Stephens M (2006) Corangamite Salinity Action Plan 2005-2008. Corangamite Catchment Management Authority, Colac, Victoria

NLWRA (2001) Australian Dryland Salinity Assessment 2000. National Land and Water Resources Audit, January 2001, NLWRA, Canberra, ACT, Australia

Peck AJ, Williamson DR (1987) Effects of forest clearing on groundwater. J Hydrol 94:47-65

Price RC, Nicholls IA, Gray CM (2003) Cainozoic igneous activity. In: Birch WD (ed) Geology of Victoria, Geological Society of Australia Special Publication 23, Geological Society of Australia, Victoria, pp 361-375

Rosengren NJ (1973) Lake Connewarre and the Barwon Estuary: Victoria's resources. September-November 1973, pp 19-22

Rusden GW (1872) The discovery, survey and settlement of Port Phillip. Williams and Norgate, London

Salama RB, Otto CJ, Fitzpatrick RW (1999) Contributions of groundwater conditions to soil and water salinization. Hydrogeol J 7(1):46-64

SCA (1978) The dryland salting problem in Victoria: review, analysis and proposals. Soil Conservation Authority, Victoria

Selwyn ARC (1856) Report on artesian wells: votes and proceedings of the Legislative Assembly, Victoria, Australia, Government Printer, Victoria

Tickell SJ, King R (1992) Lake and lunette deposits near Beeac. Report 1992/14, Geological Survey of Victoria

Todd W (1835) The Todd Journal 1835. Andrew alias William Todd (John Batman's recorder) and his Indented Head Journal 1835, Geelong Historical Society 1989, Geelong, Victoria

Wasson RJ, Donnelly TH (1991) Palaeoclimatic reconstructions for the last 30,000years in Australia: a contribution to prediction of future climate. Technical Memorandum 91/3, CSIRO Division of Water Resources, Canberra, Australia

Williams MAJ, Dunkerlay DL, DeDeckker P, Kershaw AP, Stokes T (1993) Quaternary environments. Arnold, Melbourne

Wagner R (2005) If the salt loses its savior...? Farm Pol J 2(4):7-17

Withers WB (1870) The history of Ballarat from the first pastoral settlement to the present time, facsimile edn 1980. Queensberry Hill, Carlton, Australia

Wood WE (1924) Increase of salt in soil and streams following the destruction of the native vegetation. J R Soc Western Australia $10: 35-47$ 